\title{
Defamilialisation Policies and Attitudes and Behaviour Among Mothers in Twelve European Countries. Do results for Denmark, Finland and Sweden differ from the others?
}

\author{
SIRPA WECKSTRÖM \\ Faculty of Social Sciences, Department of Social Research, University of \\ Turku, Finland
}

\begin{abstract}
Diverse family leave and day care policies create varying monetary incentives for mothers to stay at home with their children. They also affect attitudes of mothers and this should influence childcare decisions. In this study, attitudes of mothers towards cutting down on paid work for the sake of family as well as their behaviour regarding childcare at home were studied in 12 European countries. Of special interest were Denmark, Finland and Sweden, three Nordic countries with a long tradition of childcare policies supporting mothers' work participation. The data is based on the European Social Survey (ESS) Round 2, conducted in 2004 and 2005. The least familialistic attitudes were found in Sweden, Denmark and Finland. A coarse indicator for the effectiveness of childcare policy was devised and indicated that attitudes correlated with the policies in several countries. No correspondence was found between attitudes and average times spent with children at home. Regarding the Nordic countries (particularly Sweden and Finland), the contradictions observed were consistent with childcare policies that affect shortand long-term behaviour in opposite directions. In Finland, a familialistic attitude was relatively common among mothers whose youngest child was under 1-year-old.
\end{abstract}

Keywords: attitudes, child home care, childcare policy, mothers, paid work, part-time work

\section{Introduction}

Denmark, Finland and Sweden can be ascribed as forerunners of policies supporting women's participation in paid work. In these countries, the employment rates for women have been nearly as high as men's for a long time, whereas in several Southern European countries, the employment rates for genders still showed substantial differences (even if the gaps have narrowed) at the turn of the 2010's (OECD 2011). Cross-country variation in women's employment has often been linked with differences in family policies. Public day care and generous maternity and parental leaves, 
in particular, enhance the possibilities of women to reconcile motherhood with paid work, enabling high employment rates (Esping-Andersen 1999; Gornick and Meyers 2003). Yet, decisions regarding employment and care giving are made in a larger context where policies interact with culture to influence the choices of women (Pfau-Effinger 1998 , 2004). This essentially means that cultural norms regarding maternal employment should have a bearing on mothers' behaviour. Support for this view is obtained from studies regarding the connection between the attitudes of individuals towards women's gender roles and women's employment (e.g. Fortin 2005; Nordenmark 2004).

This article focuses on the outlook of mothers regarding the normatively appropriate behaviour of a woman concerning the choice of family responsibilities in place of paid work. The correspondence of attitudes with policies, and further, with behaviour of the mothers, was analysed. There is some indication that attitudes are not independent from policies but should be affected by them (Sundström 1999; Sjöberg 2004). Policies are expected to affect the attitudes firstly, by signalling to individuals what is normatively appropriate behaviour of women and secondly, by influencing the ability of women to reconcile paid work with family responsibilities (Sjöberg 2004). At the same time, attitudes may have a bearing on policy formation. When people favour and support a policy, the government will be encouraged to continue, enhance and expand it. Conversely, if the policy is unpopular, there may be calls for it to be amended, repealed or replaced by another policy (Jo 2010,3). Based on the bidirectional relationship between attitudes and policies, these two aspects should be in line. On the other hand, since policy-making is also affected by other factors, such as interests and power relations (Jo 2010), there is also the possibility that a gap exists between policies and attitudes of individuals towards the behaviour that is encouraged/discouraged by the policies.

Attitudes are measured by asking the respondents whether they think that ' $a$ woman should be prepared to cut down on her paid work for the sake of her family'. Those women were selected to the study whom the choice between childcare at home and work participation concerns (or has recently concerned), that is, mothers of children under 13 years old. In line with this, behaviour was studied regarding the precise time mothers had stayed at home because of childcare, instead of total female employment rate. The role of attitudes with regard to behaviour motivates the consideration of non-participation tied by mothers to childcare at home (instead of in general nonparticipation or participation in paid work). In addition, by focusing on information given by mothers, the study attempts to give a complementary aspect to earlier literature regarding the importance of childcare on working patterns of the mothers.

There is much already known regarding the employment patterns of mothers in various countries and it appears that institutional support for mothers' employment explains a substantial part of cross-country variations (e.g. Geyer and Steiner 2007; OECD 2007; Stier and Lewin-Epstein 2001; Uunk, Kalmijn and Muffels 2005). In addition 
to interventions targeted to mothers with young children (e.g. publicly supported childcare) also such conditions that are associated with cross-national differences in general women's employment, such as the level of unemployment, affect mothers' employment (see Nieuwenhuis, Need and Van der Kolk 2012; Pettit and Hook 2005).

The approach adopted focuses on childcare, excluding other reasons that keep mothers from participating in paid work such as other responsibilities related to family and home, or inability to find a job. In those countries in particular where a job protected family leave is short, a mother may end up leaving her job in order to take care of her child. When she is ready to return to work, it might not be possible to find a new job right away. In such cases, even if non-participation may be partly a consequence of an earlier child home care period (and indirectly affected by undeveloped childcare policies), it is not actualised by childcare at home.

The main aim of this study is to find out whether employment supportive policies in the three Nordic countries are reflected in the attitudes of mothers and in the durations of childcare at home. On a more general level, it is determined whether there are correspondences between national policies, attitudes of mothers and, further, their behaviour related to childcare at home. Consistencies that may exist do not show that one aspect has caused the other. For example, causality between policies and attitudes may also be in the reverse direction (see above). Nevertheless, even in the case national policies are understood as representation of ideologies on a macro level, they may, through affecting values and behaviour, further influence and maintain the ideologies of the individuals (Nordenmark 2004, 234). A profound assumption here is that when a consistency exists, policies have affected attitudes to at least some extent.

A number of European countries were studied to represent diverse family leave and day care policies and different working patterns of the mothers. In addition to the three Nordic countries, the following countries were included: Austria, Belgium, France, Germany, Greece, the Netherlands, Portugal, Spain and the United Kingdom. The mothers investigated had children born in the 1990s or early 2000s. Despite changes that occurred in national policies during this period, basic differences between the countries did not fade. When childcare policies are discussed in more detail, the focus is near the year 2000 .

This article proceeds as follows. To begin with, an indicator for policy effectiveness is devised to facilitate the assessment of the correspondence of mothers' attitudes with policies. That section is followed by sections for Hypotheses, Data and methods and Results. The correspondence of attitudes with policies was analysed first, followed by a study on correspondence of attitudes with behaviour. Behaviour of mothers was studied as total time spent full-time at home and at part-time work because of childcare. In the Discussion section, the focus is on the three Nordic countries and finally, the article concludes with a Summary section. 


\section{Effectiveness of childcare policies}

The effectiveness of childcare policies in this context is described by defamilialisation. The concept has been adopted from the classifications of Esping-Andersen (1999) and Leitner (2003) and modified to the specific needs of this study. For Esping-Andersen, the level of defamilialisation refers to the extent to which the caring responsibilities of families are diminished by public or private provision of care. When the main responsibility of care is left to families, the system is familialistic. Leitner considered the following two aspects of childcare policies: existence/non-existence of paid parental leave and formal, either public or private, care for children under 3-years-old. The basis of payment is also taken into consideration in the present study. Further, the focus is more clearly on public interventions and preschool aged children are also included in the consideration.

An indicator reflecting effectiveness is devised for both fields of childcare policies and the final defamilialisation value is based on these two indicators. The statement used to measure attitudes refers to an obligation, rather than to a privilege, to cut down on paid work on behalf of a family. In line with this, the indicators are constructed so that a high final defamilialisation value signifies a strong facilitation of work participation without a necessity to reduce working hours.

\section{Family leave defamilialisation}

With regard to family leave legislation, Denmark, Finland and Sweden are markedly different from the other countries studied. In these countries, the parental leave benefits are earnings related, whereas in the other countries considered only the maternity leave periods have been associated with a compensation that covers a considerable part of the wage loss (De Henau, Meulders and O’Dorchai 2007a; Gornick and Meyers 2003, 124 125). Around the year 2000, a flat-rate principle was used in Austria (until the child was 2-years-old), Belgium (3 months duration) and Germany (until the child was 2-yearsold; 3rd year unpaid). ${ }^{1}$ In Greece (3.5 months duration), the Netherlands (3 months duration, a standard take-up at 6 months with 50\% working time), Portugal (3 months duration), Spain (until the child was 3-years-old) and the United Kingdom (3 months duration; 4 weeks in the first year), parental leaves were unpaid. In France, there was no compensation for those mothers who had only one child, and mothers with at least two children were entitled to a flat-rate compensation until the child was 3-years-old.

The outcomes of family leave legislation regarding home care or work participation depends in principle whether one is interested in the short-term or long-term consequences on a mothers' work-care situation. Looking at short-term consequences, then all family leaves are familialistic in nature. The longer the leave period, the stronger the effect is. It can further be argued that monetary compensation increases familialisation. However, the long-term effect of a reasonable long and well-compensated family leave is in the reverse direction (Björnberg 2002; Sundström and Duvander 1998). A leave 
of a reasonable length enables a mother to stay at home during the neediest months of the child without the risk of losing a job. When a monthly payment is based on wages before the birth of the child, there is a strong incentive to be well established in the labour market prior to the birth of the child, facilitating returning to paid work. Since the focus here is on long-term consequences, it can be concluded that family leave defamilialisation is strongest in the three Nordic countries.

What differentiates the Nordic countries from each other is the child home care allowance that exists in Finland. Mothers in Finland are backed to stay at home until the child's third birthday, whereas in Sweden and Denmark the end of the parental leave period occurs when the children are around 1-year-old (e.g. Gornick and Meyers 2003). ${ }^{2}$ The child home care allowance is based on a flat-rate principle and is, consequently, less appealing for working mothers than the preceding benefits. Nevertheless, the choice of a prolonged homemaker status is more attractive and it has even been stated that Finland has taken a turn towards neo-familialism (Jenson and Sineau 2001, 259; Mahon 2002).

Can one then expect that attitudes among Finnish mothers differ from attitudes among mothers in the other two Nordic countries? Answering this question would be facilitated if one would know whether longer-term family leaves encourage or discourage attachment to paid work among the mothers. It has been stated that while reasonable long leaves strengthen ties to the labour market, longer leaves (two to three years) may loosen the ties (Gornick and Meyers 2003, 240-241; OECD 2001, 146). However, employment statistics do not unambiguously support this notion. Even if the employment rate for Finnish mothers with children under 3-years-old is among the lowest in Europe, for those mothers whose children are somewhat older it is among the highest (OECD 2005, 2007). Due to the unclear situation regarding the effects of leave extensions, the focus is overall on the first year, rather than the following two years of the maximum leave period.

\section{Day care defamilialisation}

Regardless of how long and how well compensated the family leave is, it does not facilitate the reconciliation of motherhood with paid work if there is no alternative for maternal care following the leave period. With regard to day care policies, Denmark, Finland and Sweden differ from the other countries studied in that practically all children are entitled to public day care place at a reasonable cost. In Belgium and France, public care for small children is not universal but, however, more widespread than in the rest of the countries studied (De Henau, Meulders and O'Dorchai 2007b; Gornick and Meyers 2003). Also in those countries where public care for small children is rare, a considerable portion of the children attends preschool, typically available for children from aged 3 or 4 years until the age when compulsory schooling begins. Preschool hours do not however correspond to hours in full-time work (De Henau et al. 2007b). 
When full-time care is not achievable, a mother may facilitate the reconciliation of motherhood and paid work by working shorter hours. A considerable number of mothers in particular in the Netherlands and also in Austria, Germany and the UK work part-time (Eurostat 2005). In Southern Europe, inflexible aspects in labour markets have impeded firms from creating part-time jobs, and even if there have been state reforms to promote part-time work, proportions of mothers working part-time have been low (Fagan 2003; Ruivo, Gonzáles and Varejăo 1998).

\section{Devising a defamilialisation indicator}

The following conceptions provide in this work a foundation for family leave defamilialisation: paid leave increases long-term employment among mothers (see also Heymann et al. 2004), and paid leave is adequate when it is available for working mothers in a manner that allows them to care for their children, maintain job security and continue to financially contribute in order to support their family (Heymann et al. 2004, 7). Accordingly, defamilialisation takes place when mothers are enabled to take care of their children at home without the loss of their previous job or previous standard of living or a provider's role. In this work, defamilialisation is considered to be strongest when mothers are allowed to stay at home during the first 12 months from the beginning of the maternity leave period, and when the entire leave period is covered by an earnings related compensation so that the compensation amounts to a considerable part of the wage loss. Again, flat-rate compensation is linked with a weaker form of defamilialisation. When parental leave is not compensated, the effects are restricted to the possibilities of mothers to return to their previously held jobs.

In day care defamilialisation, the focus is on children under 3-years-old. Regarding the availability of public care, the most appropriate measure would be the percentage of those children who would qualify if parents would choose this option. Information about these percentages is, unfortunately, scarce. In this work, actualised participation rates in public care are considered, and this data is complemented with the consideration whether the care is guaranteed for all children (e.g. Kangas and Rostgaard 2007). A further aspect is the proportion of childcare costs of the average wages for women. Regarding pre-school aged children, the opening hours are taken into consideration. Facilities with longer operating hours reduce the need to cut down on paid work, while facilities with shorter operating hours may lead to a situation where a mother has to choose between non-participation and a part-time job with short working hours.

The family leave indicator (Appendix, Table A1) is constructed as follows: during the first year, each month with an earnings-related compensation is 1 point and each month compensated by a flat-rate principle is 0.5 points. Unpaid parental leave that lasts until the end of the first year is 1 point, whereas shorter unpaid parental leave increases the score with 0.5 points. Final scores are normalised by dividing them with the maximum value (12). The maximum value of this indicator for a country is 
1 with all the other values between 0 and 1 . Due to this relatively rough approach to value different policy schemes, the final scores should be regarded directional rather than expressing comprehensively effectiveness. The same also applies to day care defamilialisation and final defamilialisation scores.

In the day care indicator the highest enrolment rate is given the value of 1 and other rates are standardised by the highest one (Appendix, Table A2). The existence of a guarantee for all children increases the score with 1 point and a partial guarantee (Belgium; $\geq 21 / 2$ years) with 0.5 points. Table A2 shows that relative fees are lowest in Austria. It is to be noted, however, that only a small proportion of children in Austria participate in this type of formal care (Bradshaw and Finch 2002), and a comparable childcare might not be available for all children. Due to this restriction, the weight of the childcare fee in the indicator is lower (the lowest relative fee is given the value $0.5)$ than the weight of the other aspects included. The longest operating hours for older children is given the value 1 and the other opening hours are standardised by the highest one. Finally, the highest sum of the considered four values is given the value 1 and the other sums are standardised by the highest one.

The final defamilialisation score is obtained as the sum of the two types of defamilialisations. Owing to the key importance of non-maternal childcare on mothers working possibilities (e.g. Gornick and Meyers 2003; Uunk et al. 2005), the value of day care defamilialisation has been doubled. ${ }^{3}$ The resulting final values are given in Table A3 (see Appendix). The values for Denmark, Finland and Sweden are highest and clearly differ from those for the other countries studied.

\section{Hypotheses}

An assumption here is that the 'net effect' of the two fields of childcare policies on mothers' attitudes depends on the extent to which the reconciliation of motherhood and paid work is facilitated. This is based on how policies should affect the attitudes (signalling effect relating to normatively appropriate behaviour and facilitating reconciliation; see Introduction). In general, policies that convey to mothers that work participation is a normatively appropriate behaviour also support the reconciliation of motherhood with paid work. However, during the very early childhood, the two mechanisms are in discord. This applies in particular to the three Nordic countries that are included in this paper. In these countries, the reconciliation is facilitated by strong interventions in both fields of childcare policies and interventions are in a row so that child home care is a normatively appropriate behaviour during a relatively short period after the birth of the child (short-term familialisation) and work participation is a social norm beyond that period. 
A central expectation here is that strong support for full-time employment among the mothers (high value on long-term defamilialisation, cf. Table A3 in the Appendix) decreases the probability that a mother has a familialistic attitude. When instead, possibilities to work full-time are restricted for a long period (low value on long-term defamilialisation), the signalling effect related to non-participation or partial participation in paid work as a normatively appropriate behaviour is also strong and attitudes are expected to be more often familialistic. The following three hypotheses are based on these expectations and aforementioned discussions regarding short-term familialisation:

Hypothesis 1. Attitudes are least familialistic in the three Nordic countries. This hypothesis is based on the expectation that long-term defamilialisation affects attitudes of mothers (cf. Table A3 in the Appendix).

Hypothesis 2. Attitudes among mothers of infants are more familialistic than attitudes among other mothers. This hypothesis is based on what childcare policies convey regarding normatively appropriate behaviour during very early childhood and concerns, especially the three Nordic countries where strong short-term familialisation is followed by strong long-term defamilialisation. ${ }^{4}$

Hypothesis 3. Attitudes among mothers and average time they have spent at home are not in line in a cross-country comparison. The expectation was that long-term defamilialisation, rather than short-term familialisation, affects attitudes among mothers in the countries concerned (Hypothesis 1). However, because the latter markedly affects total times spent with children at home, attitudes and behaviour might not correlate with each other in a cross-country comparison. Particularly in the Nordic countries where strong short-term familialisation is part of strong long-term defamilialisation, contradictions can exist. That is, low levels of familialistic attitudes (Hypothesis 1) exist in combination with relatively long average durations of childcare at home. Similarly, in some countries where attitudes are expected to be more familialistic than in the Nordic countries (as expected based on long-term defamilialisation scores, cf. Table A3 in the Appendix) non-compensated parental leaves (low scores on short-term familialisation, cf. Table A1 in the Appendix) may affect choices so that some mothers return quickly to paid work and this might shorten average durations of childcare at home.

\section{Data and methods}

The data is based on the European Social Survey (ESS) Round 2, conducted in 2004 and 2005. The sample was composed of women aged 20 to 50 who had own, adopted, foster or partner's child(ren) under 13 years old living in the same household. The numbers of mothers studied were 238 in Austria, 192 in Belgium, 188 in Denmark, 206 in Finland, 245 in France, 285 in Germany, 246 in Greece, 247 in the Netherlands, 237 in Portugal, 157 in Spain, 204 in Sweden and 293 in the United Kingdom. Ques- 
tions regarding time spent at home full-time and at part-time work were asked only of those mothers who had participated in paid work. The criterion was that a woman reported at least half a year of continuous participation in either full-time or part-time (over 19 hours/week) work.

Attitudes of mothers were measured by the statement: 'A woman should be prepared to cut down on her paid work for the sake of her family'. The five answering categories for this statement were: (1) Agree strongly, (2) Agree, (3) Neither agree nor disagree, (4) Disagree and (5) Disagree strongly.

The total duration mothers had spent at home caring for children full-time was measured by the question: 'Including any time spent on maternity or parental leave, around how long in total have you spent full-time at home because you were caring for your child(ren)?'Total duration spent at part-time work due to child caring was measured by the question: 'Around how long in total have you spent in part-time work rather than full-time work because you were caring for your child(ren)?' The seven answer options for each question were: (1) No time at home full-time/no time at part-time work rather than full-time work because of children, (2) Up to six months, (3) More than six months, up to twelve months, (4) More than a year, but up to two years, (5) More than two years, but up to four years, (6) More than four years, but up to ten years and (7) More than ten years.

The percentage of mothers who thought that a woman should be prepared to cut down on her paid work for the sake of her family are presented for each country studied. The percentage of mothers with a familialistic attitude are further presented separately for mothers whose youngest child is under 1-year-old and for mothers whose youngest child is from 1- to 2-years-old. The percentage of mothers with a familialistic attitude are compared with the final calculated values of defamilialisation.

The average durations of full-time childcare at home and of part-time work are presented for all mothers as well as for mothers who had spent at least some time at home due to childcare. The percentage of mothers with varied durations of full-time care at home and at part-time work were also determined. To assess the relationship between attitudes and behaviour, the average durations of full-time care at home and of part-time work are compared with the percentages of mothers with a familialistic attitude (rank orders). In addition, the correspondence of familialistic attitudes with familialistic behaviour (percentage of mothers reporting long durations of childcare at home and percentage of mothers reporting any time at part-time work) is studied. All statistics have been calculated using weighted data (design weight), while numbers of mothers are presented in a non-weighted form. The design weights are used to correct for slightly different probabilities of selection, thereby making the sample more representative of a 'true' sample of individuals in each country (ESS EduNet 2013). 


\section{Results}

\section{Attitudes of mothers}

The percentage of mothers who considered that a woman should be prepared to cut down on her paid work for the sake of her family varied from $12.3 \%$ in Sweden to $69.5 \%$ in Portugal; there was thus a clear cross-country variation in attitudes, see Table 1. In Denmark and Finland, mothers also infrequently thought that a woman should be prepared to cut down on her paid work. Therefore, attitudes were least familialistic in the three Nordic countries, as was expected based on strong long-term defamilialisation (Hypothesis 1). ${ }^{5}$

In Finland (and Denmark), an on-going or just ended maternity/parental leave increased the probability of reporting a familialistic attitude, but not in Sweden (Table 1). The expectation based on short-term familialisation (Hypothesis 2) thus attained partial support. Besides the two Nordic countries, having a baby increased familialistic attitudes in a few additional countries and decreased it in a few. However, it is important to note that the numbers of mothers with new born children are relatively low and that differences between attitudes of mothers with the youngest child belonging to different age categories was statistically significant (at 0.05 level) only in Finland. Overall, results obtained do not necessarily apply generally to the category of mothers in question.

Table 1. Familialistic attitudes among the mothers.

\begin{tabular}{|c|c|c|c|c|c|c|}
\hline & \multicolumn{2}{|c|}{ All mothers } & \multicolumn{2}{|c|}{$\begin{array}{l}\text { Youngest child } \\
<1 \text { year old }\end{array}$} & \multicolumn{2}{|c|}{$\begin{array}{l}\text { Youngest child } \\
1-2 \text { years old }\end{array}$} \\
\hline & $\%$ & $\mathrm{n}$ & $\%$ & $\mathrm{n}$ & $\%$ & $\mathrm{n}$ \\
\hline Sweden & 13.8 & 203 & 14.3 & 21 & 11.4 & 35 \\
\hline Denmark & 18.6 & 188 & 33.3 & 15 & 16.7 & 36 \\
\hline Finland* & 23.3 & 205 & 53.9 & 26 & 15.9 & 44 \\
\hline Netherlands & 31.4 & 246 & 18.8 & 17 & 33.9 & 56 \\
\hline Belgium & 42.1 & 191 & 31.8 & 22 & 44.7 & 38 \\
\hline Greece $^{1}$ & 44.7 & 245 & - & & 44.5 & 58 \\
\hline United Kingdom & 47.3 & 293 & 66.7 & 13 & 48.3 & 65 \\
\hline Austria $^{1}$ & 49.8 & 234 & - & & 37.8 & 40 \\
\hline France & 52.3 & 245 & 46.6 & 15 & 44.9 & 51 \\
\hline Spain & 55.3 & 156 & 72.3 & 18 & 62.6 & 32 \\
\hline Germany & 57.4 & 282 & 57.2 & 16 & 56.2 & 41 \\
\hline Portugal & 69.5 & 236 & 73.9 & 15 & 81.6 & 43 \\
\hline
\end{tabular}

* Statistically significant difference at the country level.

${ }^{1}$ Number of mothers with a child under one year old was very low.

${ }^{2}$ Age of the youngest child is the difference between the year the mother was interviewed and the year her child was born. Information regarding the month the child was born was not available. Therefore, the second categorisation (youngest child 1-2 years old) may include children who have not yet had their first birthday. 
In Figure 1, the correlation of attitudes with the final levels of defamilialisation for the countries studied is shown. The attitudes appear to correlate well with defamilialisation scores for several countries (Austria, Belgium, Denmark, Finland, France, Germany, Portugal, Spain and Sweden); a least-square line was fitted to the points of these countries (see Figure 1). For some countries, however, attitudes were less familialistic than what could have been expected based on defamilialisation scores (Greece, the Netherlands and the UK). This might be in part related to the complicated relationship between the two aspects. That is, an attitudinal climate may affect policies with a time lag and therefore the observed inconsistency does not necessarily refer to a corresponding inconsistency in the longer run. For example, in the Netherlands day care costs have decreased after data collection (Plantenga and Remery 2009).

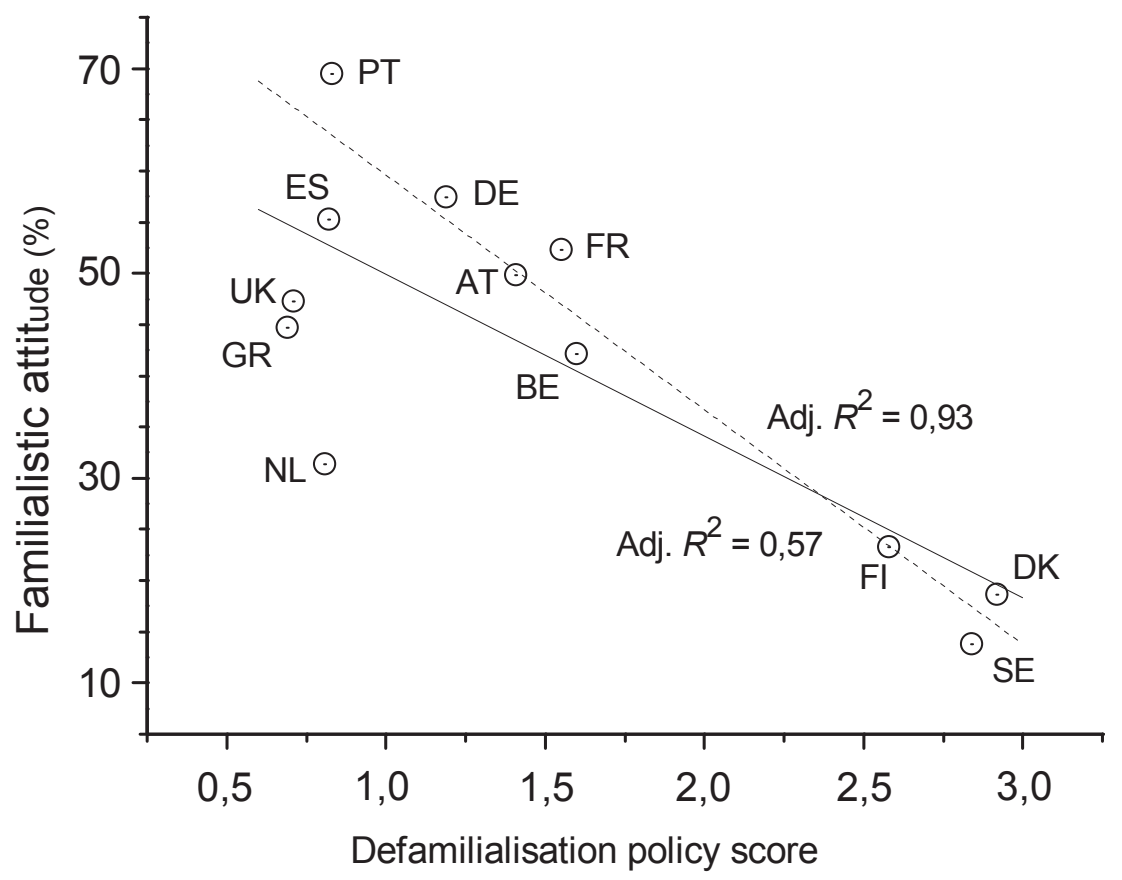

Figure 1. Familialistic attitude (\%) in the twelve countries Austria (AT), Belgium $(\mathrm{BE})$, Denmark (DK), Finland (FI), France (FR), Germany (DE), Greece (GR), the Netherlands (NL), Portugal (PT), Spain (ES), Sweden (SE) and the United Kingdom (UK) versus the defamilialisation policy score. The equation for the solid line is $y=65,77-15,8 x$; Adj. $R^{2}=0,571$. The dashed line shows a fit to nine countries (AT, BE, DK, FI, FR, DE, PT, ES and SE; the equation is $y=82,46-22,88 x$; Adj. $\left.R^{2}=0,933\right)$. 


\section{Relationship between attitudes and behaviour}

Although mothers in Finland and especially in Sweden infrequently expressed a familialistic attitude, the duration of full-time childcare at home was typically relatively long (see Table 2 and Table A4 in the Appendix). Thus, the attitudes of mothers and their behaviour strongly conflicted with each other. This result corresponds with the expected effects of short-term familialisation on attitudes and behaviour (Hypothesis 3 ).

Table 2. Average times spent full-time at home and at part-time work due to child caring responsibilities.

\begin{tabular}{lcclcc}
\hline & \multicolumn{3}{c}{ Full-time at home } & & \multicolumn{2}{c}{$\begin{array}{c}\text { At part-time work } \\
\text { All FTH }>1\end{array}$} & All PTW $>1$ \\
\hline UK & 5.06 & 5.34 & Netherlands & 3.96 & 5.39 \\
Finland & 4.77 & 4.81 & Austria & 3.70 & 4.91 \\
Austria & 4.76 & 5.02 & Germany & 3.49 & 4.85 \\
Germany & 4.72 & 4.92 & Sweden & 3.36 & 4.84 \\
Sweden & 4.46 & 4.53 & UK & 3.28 & 5.02 \\
France & 4.01 & 4.27 & Belgium & 2.97 & 5.04 \\
Denmark & 3.84 & 3.93 & France & 2.91 & 5.08 \\
Netherlands & 3.75 & 4.16 & Denmark & 1.99 & 4.37 \\
Belgium & 3.43 & 3.85 & Spain & 1.82 & 3.53 \\
Greece & 3.13 & 3.81 & Greece & 1.62 & 3.59 \\
Spain & 3.00 & 3.73 & Finland & 1.56 & 3.87 \\
Portugal & 2.66 & 2.93 & Portugal & 1.48 & 2.63 \\
\hline
\end{tabular}

1) no time at all, 2) less than six months, 3) from six months to a year, 4) from a year to two years, 5) from two to four years, 6) from four to ten years, 7) more than 10 years.

When one considers all the countries studied, familialistic attitudes and the durations of full-time care at home do not positively correlate with each other. Rank orders with respect to these aspects are shown in Table 3. Regarding full-time care at home, the greatest gaps between rank orders for the two aspects are found in Portugal, Spain, Finland and Sweden. Regarding part-time work, the clearest inconsistencies with attitudes were found in Portugal, Sweden and the Netherlands. Although a large majority of mothers in Portugal considered that a woman should be prepared to cut down on her paid work, part-time work was uncommon (see also Table A5 in Appendix). In Sweden, the situation was the opposite; despite a very low percentage of mothers supporting a woman's obligation to cut down on paid work, the average time spent at part-time work was relatively long. On the whole, how commonly mothers reported a familialistic attitude was not decisive for cross-country variation in familialistic behaviour among the mothers (see also in the Appendix, Figure 2Aa for percentage of mothers reporting long durations of childcare at home and Figure $2 \mathrm{Ab}$ for percentage of mothers reporting any time at part-time work). 
Table 3. Rank orders with respect to familialistic attitudes, average times spent full-time at home (FTH) and average times spent at part-time work (PTW).

\begin{tabular}{lrrlrr}
\hline & $\begin{array}{c}\text { Familial. } \\
\text { attitude }\end{array}$ & \multicolumn{1}{c}{ FTH } & & $\begin{array}{c}\text { Familial. } \\
\text { attitude }\end{array}$ & PTW \\
\hline Portugal & 1 & 12 & Portugal & 1 & 12 \\
Germany & 2 & 4 & Germany & 2 & 3 \\
Spain & 3 & 11 & Spain & 3 & 9 \\
France & 4 & 6 & France & 4 & 7 \\
Austria & 5 & 3 & Austria & 5 & 2 \\
UK & 6 & 1 & UK & 6 & 5 \\
Greece & 7 & 10 & Greece & 7 & 10 \\
Belgium & 8 & 9 & Belgium & 8 & 6 \\
Netherlands & 9 & 8 & Netherlands & 9 & 1 \\
Finland & 10 & 2 & Finland & 10 & 11 \\
Denmark & 11 & 7 & Denmark & 11 & 8 \\
Sweden & 12 & 5 & Sweden & 12 & 4 \\
\hline
\end{tabular}

Note: Numbers in the table refer to positions of countries in comparison to other countries. As an example, in Portugal the average period spent full-time at home was shorter than in any other country (rank order 12) and the percentage of mothers reporting a familialistic attitude was higher than in any other country (rank order 1).

Based on the analysis, policies and attitudes show an overall correlation but attitudes do not appear to have much bearing on the cross-country variation of mothers' behaviour. ${ }^{6}$ This does not however mean that policies would not affect (directly) the behaviour of mothers. Based on the long-term familialisation scores (Table A3 in the Appendix), policies and behaviour (average time spent full-time at home and at part-time work, respectively) do not correlate with each other (p-values are 0.282 and 0.802 , respectively.) However, in countries with high scores on family leave defamilialisation/shortterm familialisation, a considerable part of mothers had stayed at home full-time for relatively long taking care of their children, with Denmark as a slight exception (see Tables A1 and A4 in the Appendix; notice that the scores for Austria and Germany would have been higher if one would have considered the maximum leave period, instead of the first year).

A broader variation can be observed between countries showing lower scores on family leave defamilialisation/short-term familialisation, particularly when comparing the UK and Southern European countries, i.e. countries where also the day care defamilialisation scores (and long-term defamilialisation scores) were relatively low. Thus, when interventions on both fields of childcare policies were relatively weak, other factors appeared to be decisive for mothers' decisions regarding childcare at home and work participation. A low day care defamilialisation score (Table A2 in the Appendix) and part-time work 
were often connected (e.g. results for the Netherlands and the UK; see Table 2 and Table A5 in the Appendix), but there were also exceptions such as the Southern European countries (part-time work uncommon) and Sweden (part-time work common).

\section{Discussion}

This study examines paid employment and childcare responsibilities of mothers in 12 European countries. Attitudes of mothers towards cutting down on paid work for the sake of family and the duration of the homecare of children were analysed. In conformity with strong institutional support for the attachment of women to paid work, attitudes were least familialistic in Sweden, Denmark and Finland. However, mothers in Sweden and Finland had stayed with their children at home for a relatively long periods. The strong contradictions observed between the attitudes and behaviour can be understood in light of a strong short-term familialisation (generous family leaves).

The non-familialistic attitudes of mothers in Sweden were further at variance with the commonness of part-time work. Legislation that enables work time reduction (Båvner 2001) and access to public day care with long operating hours allows Swedish mothers to choose between full-time work and part-time work. Overall, the view that lacking restrictions related to full-time work is linked with non-familialistic attitudes was supported by results regarding mothers in the studied Nordic countries.

The only period when the choice of full-time work is constrained in the Nordic countries is when mothers are entitled to maternity/parental leave benefits but not yet to day care services. An on-going, or just ended, maternity or parental leave increased the probability of a mother to report a familialistic attitude in Denmark and Finland. The effect was clear particularly in Finland, where a majority of those mothers with a child under 1-year-old thought that a woman should be prepared to cut down on her paid work. In contrast, those mothers in Finland who had recently made the decision whether or not to prolong the home care period, i.e. mothers with children from 1- to 2-years-old, rarely reported a familialistic attitude. A familialistic attitude was reported somewhat more often by Finnish mothers than by mothers in Denmark and particularly in Sweden. Nevertheless, the attitudes of Finnish mothers were much closer to those of mothers in the two other Nordic countries than to those in most other countries studied. Overall, the effect of the child home care allowance on mothers' attitudes was apparently quite small.

An important focus of childcare policies in the Nordic countries has been to promote gender equality by encouraging fathers to take parental leave as well (Eydal and Rostgaard 2011). At the time of data collection (2004 to 2005) there had been a fathers' quota of parental leave in Sweden already since 1995 whereas in Finland it was quite new, only introduced in 2003, and in Denmark it had been removed (Lammi-Taskula, 2009). The especially strong gender equality ideology in Sweden was perhaps reflected in the fact that familialistic attitudes among mothers were exceptionally low. 
The results for Portugal, showing strongly familialistic attitudes and non-familialistic behaviour, were in sharp contrast to the results for the Nordic countries. The high proportion of mothers that considered a woman should be prepared to cut down on her paid work corresponded with weak long-term defamilialisation. In particular, inadequate day care services could be an institutional signal to mothers to cut down on paid work, or at least to be prepared to do it. The strong contradiction observed between attitudes and behaviour suggests that mothers either had very little need, or insufficient possibilities, to cut down on paid work. ${ }^{7}$ Of the two assumptions, the first refers to a situation where the supply of non-maternal care is considered as adequate, whereas the second implies that mothers' behaviour is affected by factors other than their ideologies. Considering that a full-time second earner is typically required to sustain the family in Portugal (OECD 2004), the most important one among such factors probably is a necessity to work for economic reasons (see also Uunk et al. 2005). In summary, the inconsistency observed between attitudes and behaviour of mothers is most likely related to a necessity to work for economic reasons, along with the availability of informal childcare substitutions that enable work interruptions of a rather short duration (Council of Europe 2009).

The availability of subsidised childcare, as well as possibilities to work part-time in jobs that correspond to ones qualifications, are known to have positive effects on the labour market participation of mothers (e.g. Del Boca, Pasqua and Pronzato 2008; Simonsen 2006). Therefore, it would be tempting to explain the relatively low female employment rates in Greece and Spain by shortcomings in these conditions. However, the results obtained do not suggest that in particular childcare at home restricts mothers' work participation. In reality, grandmothers commonly take care of children in Southern European countries (Arpino, Pronzato and Tavares 2010; Katsimi and Tsakloglou 2000), which compensates (at least partially) for the lack of day care services. It is important to note, though, that especially in Greece, a considerable part of mothers had never participated in paid work ( $20 \%$; data of this study) and it remains unanswered which influence child caring responsibilities had on the behaviour of these mothers. Despite this limitation, it seems that there are different reasons for the low female employment rates in addition to childcare at home. One major reason is most likely an inadequate supply of jobs. In both of these countries, labour markets tend to discriminate women, and the unemployment situation has been clearly worse for them as compared to that for men (Flaquer 2000; Ferreira 2009). Gender differences have, however, narrowed towards the end of the 2000s, especially in Spain (OECD 2011). 


\section{Summary}

The manner in which childcare policies are organised affects the possibilities of mothers to work outside the home, as well as the necessity for them to withdraw from paid work when children are small. The main aim of this study was to determine whether employment supportive (defamilialisation) policies in Denmark, Finland and Sweden are reflected in the attitudes of mothers and in the duration of childcare at home. On a general level, the study clarified whether there are correspondences between national policies, attitudes of the mothers and, further, their behaviour related to childcare at home.

Attitudes of the mothers were seen to vary markedly between the European countries studied. The least familialistic attitudes were found in Sweden, Denmark and Finland. In Finland, a familialistic attitude was relatively common in times of short-term familialisation. There was not adequate support, however, for the importance of the child home care allowance on mothers' attitudes. This was likely related to the optional nature of this benefit; the statement used to measure attitudes refers to an obligation rather than to a privilege to cut down on paid work on behalf of family. It is also important to note that the focus was on short-term behaviour, which does not correlate with long-term attachment to paid work.

The mothers' attitudes in the countries studied correlated quite well with the devised childcare policy index. On the contrary, the attitudes of mothers and the average durations of childcare at home did not correlate. Regarding the Nordic countries, the inconsistencies can be understood in light of childcare policies that affect attitudes and behaviour (short-term) in opposite directions. In addition to possibilities and constrains related to childcare policies, also other circumstances that are partially country specific influence how mothers divide time between paid work and child caring responsibilities. For example, economic affluence/deficiency and the availability of informal childcare may be more decisive factors for a mother's behaviour than whether or not she considers that she should be prepared to sacrifice her working hours on behalf of her family.

Overall, the results indicate that a connection exists between attitudes of mothers and childcare policies and further demonstrate that attitudes are not decisive for the crosscountry variation in durations of childcare at home. The results also suggest that low female employment rates cannot always be explained by child caring responsibilities of mothers. In countries where childcare is not the principal reason for non-participation in paid work, an increase in day care services might not lead to a corresponding increase in the female employment rate. 


\section{Notes:}

1 In the late 2000s, Austria and Germany renewed their family leave legislations. In Austria, the monetary compensation is greater if a mother returns to paid work earlier. In Germany, the period with monetary compensation is shorter than what it was previously but the compensation is based on earlier earnings (Leitner 2010).

2 Since 2002, the municipalities in Denmark have had the possibility to pay cash for care of own children, but only a very small number of mothers have used the benefit (Rantalaiho 2009). Since 2008, a corresponding benefit has been available in part of the municipalities in Sweden (Eydal and Rostgaard 2011).

3 This choice was supported by testing various ratios. With the ratio 1:2 an optimal correlation was observed for several countries (as measured by Adjusted $\mathrm{R}^{2}$; Adj. $R^{2}$ $=0.93$; Krzanowski 2007, 129). This result was obtained by selecting nine countries that best adhered to the correlation and varying the ratio. At ratios above and below two, respectively, the Adj. $R^{2}$ values moderately decreased.

4 Theoretically, familialisation of fathers could be regarded as a means of defamilialisation in this stage of life. However, since men generally earn more than women, fathers are not encouraged to take parental leave days, at least not more than those days that are reserved exclusively for them (a relatively small proportion of the total leave, see e.g. Lammi-Taskula 2009). In addition, the percentages of total benefit days used by fathers are generally low, though somewhat higher in Sweden (15.5\% in 2002 and 20\% in 2007) (Eydal and Rostgaard 2011; Plantenga and Remery, 2005, 50).

5 Controlling for a mother's age, years of education, number of children and family type did not eliminate differences between the countries (binary logistic regression analysis). The only country that did not differ in a statistically significant way from Sweden was Denmark. The difference between Sweden and Finland was smaller than the differences between Sweden and the rest of the countries studied.

6 At the country-level, the connection between mother's attitude and her behaviour was also typically weak. As to part-time work, results for none of the investigated countries reached statistical significance. As to full-time care, a statistically significant correlation (at the 0.01 level) was found only for Finland, Germany and Spain. Restricting the consideration to those mothers whose youngest child was 3 years old or older did not change this. It is not possible to conclude causality between attitudes and behaviour based on bare correlations. Nevertheless, longer-term childcare leaves (paid or unpaid) in the three countries facilitate those mothers who have a familialistic attitude to act in accordance with their attitudes and therefore it is possible that attitudes had, at least to some extent, affected the behaviour of the mothers.

7 The average number of children was lowest in Portugal. Variations in the number of children were, however, too small to explain the marked variations in times spent with children at home. 


\section{Acknowledgement}

The author would like to thank the two anonymous reviewers for constructive comments.

\section{References}

Acts of Parliament (1999). Maternity and parental leave etc. regulations 1999. http:// www.legislation.gov.uk/uksi/1999/3312/pdfs/uksi_19993312_en.pdf.

Arpino, B., C. Pronzato and L. Tavares. (2010). All in the family: informal childcare and mothers 'labour market participation. ISER Working Paper Series, No. 201224. Institute for Social and Economic Research. https://www.iser.essex.ac.uk/files/ iser_working papers/2010-24.pdf.

Båvner, P. (2001). Half full or half empty? Part-time work and well-being among Swedish women. Doctoral Dissertation Series, No. 49, Swedish Institute for Social Research. Stockholm: Stockholm University.

Björnberg, U. (2002). Ideology and choice between work and care: Swedish family policy for working parents. Critical Social Policy, 22(1), 33-52.

Bradshaw, J. and N. Finch. (2002). A comparison of child benefit packages in 22 countries. Department for Work and Pensions Research Report, No. 174. Leeds: Corporate Document Services.

Council of Europe (2009). Council of Europe family policy database. http://www.coe. int/t/dg3/familypolicy/Source/3 4 3\%20Informal\%20child\%20care $\% 20$ systems. pdf.

De Henau, J., Meulders, D. and S. O’Dorchai (2007a). Parents' care and career: Comparing

parental leave policies across EU-15. In D. Del Boca and C. Wetzels (Eds.) Social Policies, Labour Markets and Motherhood: a Comparative Analysis of European countries, pp. 63-106. Cambridge: Cambridge University Press.

- (2007b). Making time for working parents: comparing public childcare provision. In D. Del Boca and C. Wetzels (Eds.) Social Policies, Labour Markets and Motherhood: a Comparative Analysis of European countries, pp. 28-62. Cambridge: Cambridge University Press.

Del Boca, D., S. Pasqua and C. Pronzato (2008). Market work and motherhood decisions in contexts. IZA Discussion Paper, No. 3303. http://ftp.iza.org/dp3303.pdf.

Esping-Andersen, G. (1999). Social foundations of postindustrial economies. Oxford: Oxford University Press.

ESS EduNet (2013). Weighting the ESS data. European Social Survey Education Net. http://essedunet.nsd.uib.no/cms/userguide/weight/.

Eurostat (2005). Reconciling work and family life in the EU25 in 2003. Newsletter 49/2005. http://www.lex.unict.it/eurolabor/documentazione/altrestat/ eurostat120405.pdf.

Eurostat (2008). Average gross annual earnings in industry and services, by gender [tps00175]; Total of full-time employees in enterprises with 10 or more employees (ECU/EUR). http://epp.eurostat.ec.europa.eu/tgm/refreshTableAction.do?tab=tabl e\&pcode $=$ tps $00175 \&$ language $=$ en . 
Eydal, G., and D. Rostgaard (2011). Gender equality revisited - changes in Nordic childcare policies in the 2000s. Social Policy \& Administration 45(2), 161-179.

Fagan, C. (2003). Working-time preferences and work-life balance in the EU: Some policy considerations for enhancing the quality of life. European Foundation for the Improvement of Living and Working Conditions. http://www.eurofound.europa.eu/ publications/htmlfiles/ef0342.htm.

Ferreira, V. (2009). Employment policies from a gender equality perspective in Mediterranean Europe developments and challenges. In L. Ambrosi, G. TrisorioLiuzzi, R. Quagliariello, L. Santelli Beccegato, C. Di Benedetta and F. Losurdo (Eds.) Women status in the Mediterranean: their rights and sustainable development. Bari: CIHEAM, 2009. Options Méditerranéennes: Série A. Séminaires Méditerranéens, No. 87, pp. 33-44.http://om.ciheam.org/om/pdf/a87/00801049.pdf.

Flaquer, L. (2000). Family policy and welfare state in Southern Europe. WP núm. 185. Institut de Ciències Politiques i Socials. Barcelona: Universitat Autònoma de Barcelona. http://www.recercat.net/bitstream/handle/2072/1280/ICPS185. pdf? sequence=1.

Fortin, N. (2005). Gender role attitudes and the labour market outcomes of women across OECD countries. Oxford Review of Economic Policy 21(3), 416-38.

Geyer, J., and V. Steiner (2007). Short-run and long-term effects of childbirth on mothers' employment and working hours across institutional regimes: an empirical analysis based on the European Community Household Panel, IZA Discussion Paper 2693, Institute for Study of Labour (IZA). http://ftp.iza.org/dp2693.pdf.

Gornick, J.C., and M. K. Meyers (2003). Families that work. Policies for reconciling parenthood and employment. New York: Russell Sage Foundation.

Heymann, J., A. Earle, S. Simmons, S. Breslow and A. Kuehnhoff. (2004). The work, family and equity index: Where does the United States stand globally? The Project on Global Working Families. Boston: Harward School of Public Health.

Jaumotte, F. (2003). Female labour force participation: Past trends and main determinants in OECD countries. OECD Economics Department Working Papers, No. 376, OECD Publishing. http://www.oecd.org/officialdocuments/ publicdisplaydocumentpdf/?doclanguage $=$ en $\&$ cote $=e c o / w k p(2003) 30$.

Jenson, J. and M. Sineau (2001). Who cares? Women, work and welfare state redesign. Toronto: University of Toronto Press.

Jo, N. K. (2010). Values and policy attitudes: the impact of family values and family policy on maternal employment and its change from a comparative quantitative study. http://www.social-policy.org.uk/lincoln/Jo.pdf.

Kangas, O., and T. Rostgaard (2007). Preferences or institutions? Work-family life opportunities in seven European countries. Journal of European Social Policy 17(3), 240-56.

Katsimi, M. and P. Tsakloglou, P. (2000). Employment options of the future: actual and preferred working hours - Greece, research project, working paper. Dublin: European Foundation for the Improvement of Living and Working Conditions.

Krzanowski, W. J. (2007). Statistical principles and techniques in scientific and social investigations, p. 129. Oxford: Oxford University Press. 
Lammi-Taskula, J. (2009). Nordic mothers and fathers on leave: towards equal sharing? In E. Sigurðardóttir (Ed.) Parental leave, care policies and gender equalities in the Nordic countries, pp. 21-4.

http://jafnretti.is/D10/_Files/Sk\%C3\%BDrsla foreldraorlof.pdf.

Leitner, S. (2003). Varieties of familialism: The caring function of the family in comparative perspective. European Societies 5(4), 353-75.

-. (2010). Germany outpaces Austria in childcare policy: the historical contingencies of 'conservative' childcare policy. Journal of European Social Policy 20(5), 456-67.

Mahon, R. (2002). Child care: toward what kind of 'social Europe'? Social Politics 9(3), 343-79.

Nieuwenhuis, R., A. Need and H. van der Kolk (2012). Institutional and demographic explanations of women's employment in 18 OECD countries, 1975-1999. Journal of Marriage and Family 74(3), 614-30.

Nordenmark, M. (2004). Does gender ideology explain differences between countries regarding the involvement of women and of men in paid and unpaid work? International Journal of Social Welfare 13(3), 233-43.

OECD (2001). Balancing work and family life. Helping parents into paid employment. Employment Outlook 129-66. Paris: OECD. http://www.oecd.org/els/emp/2079435. pdf.

- (2004). Babies and bosses - reconciling work and family life, Vol. 3: New Zealand, Portugal and Switzerland. Paris: OECD.

- (2005). Society at a glance. OECD: Social indicators. Paris: OECD.

- (2007). Babies and bosses - reconciling work and family life: A synthesis of findings from OECD countries, Vol. 5. http://www.oecd.org/els/family/babiesandbosses-rec oncilingworkandfamilylifeasynthesisoffindingsforoecdcountries.htm.

- (2011). Employment outlook. Statistical Annex. http://www.oecd.org/employment/ emp/48616281.pdf.

Pfau-Effinger, B. (1998). Gender cultures and the gender arrangements: a theoretical framework for cross-national gender research. Innovation: The European Journal of Social Science Research 11(2), 147-66.

-. (2004). Development of culture, welfare states and women's employment in Europe. Aldershot: Ashgate.

Pettit, B. and J. Hook, J. (2005). The Structure of Women's Employment in Comparative Perspective. Social Forces 84(2), 779-801.

Plantenga J. and C. Remery (2005). Reconciliation of work and private life: A comparative review of thirty European countries. EU Experts Group on Gender, Social Inclusion and Employment (EGGSIE). European Commission, DirectorateGeneral for Employment, Social Affairs and Equal Opportunities Unit G.I. Luxembourg: Office for Official Publications of the European Communities.

Plantenga, J. and C. Remery (2009). The provision of childcare services. A comparative review of 30 European countries. European Commission's Expert Group on Gender and Employment Issues (EGGE).

Rantalaiho, M. (2009). Kvoter, valgfrihet, fleksibilitet. Indre spenninger I den nordiske familliepolitikken. Köbenhavn: NIKK. 
Ruivo, M., M. Gonzáles and J. Varejăo (1998). Why is part-time work so low in Portugal and Spain? In J. O'Reilly and C. Fagan (Eds.) Part-time prospects. An international comparison of part-time in Europe, North America and Pacific Rim, pp. 199-213. London: Routledge.

Simonsen, M. (2006). Availability and price of high quality day care and female employment. Aarhus University Economics Paper, No. 2005-08. http://ele.ifau.se/ files/papers/nsi/ncoe simonsen.pdf.

Sjöberg, O. (2004). The role of family policy institutions in explaining gender-role attitudes: a comparative multilevel analysis of thirteen industrialized countries. Journal of European Social Policy 14(2), 107-23.

Stier, H., and N. Lewin-Epstein (2001). Welfare regimes, family-supportive policies and women's employment along the life-course. American Journal of Sociology 106(6), 1731-60.

Sundström, E. (1999). Should mothers work? Age and attitudes in Germany, Italy and Sweden. International Journal of Social Welfare 8(3), 193-205.

Sundström, M. and A.-Z. E. Duvander (1998). Föräldraförsäkringen och jämställdhet mellan kvinnor och män [Parental leave policy and gender equality]. In I. Persson and E. Wadensjö (Eds.) Välfärdens Genusansikte, pp. 69-91, SOU 1998: 3. Stockholm: Fritzes.

Uunk, W., M. Kalmijn and R. Muffels (2005). The impact of young children on women's labour supply. A reassessment of institutional effects in Europe. Acta Sociologica $48(1), 41-62$. 


\section{Appendices}

Table A1. Family leave defamilialisation: short-term familialisation.

\begin{tabular}{llll}
\hline First year & \multicolumn{3}{l}{ Total duration } \\
(months) & $\begin{array}{l}\text { Compensation during } \\
\text { the parental leave } \\
\text { period }\end{array}$ & Value \\
\hline Sweden & 12 & Earnings-related ${ }^{1}$ & 1.00 \\
Denmark & 12 & Earnings-related ${ }^{2}$ & 0.92 \\
Finland & 12 & Earnings-related & 0.92 \\
Austria & 12 & Flat-rate & 0.67 \\
Germany & 12 & Flat-rate & 0.63 \\
France & 12 & Flat-rate $>1$ child/ & 0.51 \\
Belgium & & Not compensated & 0.42 \\
Spain & 6.5 & Flat-rate & 0.38 \\
Netherlands & 12 & Not compensated & 0.33 \\
Greece & 6.5 & Not compensated & 0.33 \\
Portugal & 7 & Not compensated & 0.33 \\
UK & $6.5 / 12^{4}$ & Not compensated & 0.31 \\
\hline
\end{tabular}

${ }^{1}$ In the year 2000, the total duration of leave was 15 months. After the twelve months earningsrelated compensation parents were entitled to a flat-rate compensation for three months.

${ }^{2}$ Comprises 24 weeks of additional child-care leave during which the benefit level is $60 \%$ of the benefit level during the parental leave period.

${ }^{3}$ Flat-rate compensation during the last two months (a child home care allowance).

${ }^{4}$ Includes unpaid additional leave scheme after maternity and parental leave periods.

${ }^{5}$ Does not comprise an unpaid additional maternity leave that may continue until the end of the period of 29 weeks beginning with the week of childbirth (Acts of Parliament 1999).

Sources: Bradshaw and Finch 2002; Gornick and Meyers 2003; De Henau et al. 2007a. 
Table A2. Day care defamilialisation.

\begin{tabular}{|c|c|c|c|c|c|}
\hline & \multicolumn{3}{|c|}{ Children under three years old } & \multicolumn{2}{|l|}{$\begin{array}{l}\text { Pre-school } \\
\text { aged } \\
\text { children }\end{array}$} \\
\hline & $\begin{array}{l}\text { Enrolment } \\
\text { Rate }\end{array}$ & $\begin{array}{l}\text { Guaranteed } \\
\text { childcare }\end{array}$ & $\begin{array}{l}\text { Childcare } \\
\text { fees of net }^{\text {wage }}\end{array}$ & $\begin{array}{l}\text { Opening } \\
\text { hours }^{2}\end{array}$ & Value \\
\hline Denmark & 58 & Yes & 15.0 & 10.5 & 1.00 \\
\hline Sweden & 37 & Yes & 14.5 & 11.5 & 0.92 \\
\hline Finland & 23 & Yes & 12.5 & 10.0 & 0.83 \\
\hline Belgium & 30 & No $(<2.5)$ & 18.4 & 7.0 & 0.59 \\
\hline France & 39 & No & 16.4 & 8.0 & 0.52 \\
\hline Austria & 10 & No & 12.0 & 6.3 & 0.37 \\
\hline Germany & 9 & No & 30.1 & 6.7 & 0.28 \\
\hline Portugal & 12 & No & 31.3 & 5.0 & 0.25 \\
\hline Netherlands & 2 & No & 41.0 & 7.0 & 0.24 \\
\hline Spain & 5 & No & 28.8 & 5.0 & 0.22 \\
\hline UK & 2 & No & 31.6 & 5.2 & 0.20 \\
\hline Greece & 3 & No & 31.6 & 4.0 & 0.18 \\
\hline
\end{tabular}

${ }^{1}$ The value is a proportion of childcare fees of the average net wage for full-time working women in the country concerned. Childcare fees used in the calculations are fees after subsidises, benefits and taxes for the most typical form of full-time childcare in a two parent family where both the parents work full-time (Bradshaw and Finch 2002). Net wages are based on author's own calculations. Average gross earnings for woman are based on Eurostat statistics for the year 2002, for Austria and Spain for the year 2004 (Eurostat, 2008). Tax rate used in the calculation is an average between a tax rate for a mother who earns $67 \%$ and a mother who earns $100 \%$ of average production worker earnings when a husband earns $100 \%$ of average production worker earnings (Jaumotte 2003).

${ }^{2}$ Data mainly for year 2003; see De Henau et al. 2007b.

Sources: Bradshaw and Finch 2002; De Henau et al. 2007b; Gornick and Meyers 2003; Jaumotte 2003.

Table A3. Long-term defamilialisation.

\begin{tabular}{lllc}
\hline & Value & & Value \\
\hline Denmark & 2.92 & Germany & 1.19 \\
Sweden & 2.84 & Portugal & 0.83 \\
Finland & 2.58 & Spain & 0.82 \\
Belgium & 1.60 & Netherlands & 0.81 \\
France & 1.55 & UK & 0.71 \\
Austria & 1.41 & Greece & 0.69 \\
\hline
\end{tabular}


Table A4. Percentages of mothers with regard to varied durations spent fulltime at home because of childcare.

\begin{tabular}{lrrrrr}
\hline & $\begin{array}{c}0-0.5 \text { years } \\
\%\end{array}$ & $\begin{array}{c}0.5-1 \text { years } \\
\%\end{array}$ & $\begin{array}{c}1-2 \text { years } \\
\%\end{array}$ & $\begin{array}{c}2-4 \text { years } \\
\%\end{array}$ & $\begin{array}{c}\text { More than } \\
4 \text { years } \%\end{array}$ \\
\hline Austria & 9.0 & 9.0 & 19.1 & 25.6 & $\mathbf{3 7 . 2}$ \\
Belgium & $\mathbf{3 8 . 8}$ & 19.7 & 15.3 & 5.1 & 21.0 \\
Denmark & 13.6 & 26.1 & $\mathbf{3 1 . 0}$ & 19.6 & 9.8 \\
Finland & 4.0 & 11.4 & 19.9 & $\mathbf{3 4 . 8}$ & 29.9 \\
France & $\mathbf{2 8 . 3}$ & 12.7 & 13.5 & 21.1 & 24.4 \\
Germany & 13.9 & 8.2 & 13.5 & 25.5 & $\mathbf{3 9 . 0}$ \\
Greece & $\mathbf{4 3 . 3}$ & 20.6 & 10.0 & 11.1 & 15.0 \\
Netherlands & $\mathbf{4 0 . 0}$ & 14.7 & 6.1 & 7.8 & 31.5 \\
Portugal & $\mathbf{6 2 . 7}$ & 13.4 & 10.9 & 8.5 & 4.5 \\
Spain & $\mathbf{5 1 . 9}$ & 13.1 & 12.4 & 9.5 & 13.2 \\
Sweden & 6.5 & 10.0 & 30.5 & $\mathbf{3 6 . 0}$ & 17.0 \\
UK & 13.9 & 8.0 & 10.3 & 14.9 & $\mathbf{5 2 . 8}$ \\
\hline
\end{tabular}

Note: The value for the most common time range marked in bold.

(Considering only those mothers whose youngest child is three years or older changed the most common time range in France and the Netherlands, where the range $0-0.5$ years was in the second place.)

Table A5. Percentages of mothers with regard to varied durations spent at parttime work because of childcare.

\begin{tabular}{lccccc}
\hline & $\begin{array}{c}\text { Not at all } \\
\%\end{array}$ & $\begin{array}{c}-1 \text { year } \\
\%\end{array}$ & $\begin{array}{c}1-2 \text { years } \\
\%\end{array}$ & $\begin{array}{c}2-4 \text { years } \\
\%\end{array}$ & $\begin{array}{c}\text { More than } \\
4 \text { years } \%\end{array}$ \\
\hline Austria & 31.2 & 11.5 & 14.1 & 18.6 & 24.6 \\
Belgium & 51.3 & 10.2 & 8.3 & 5.8 & 24.4 \\
Denmark & 70.5 & 9.3 & 6.0 & 6.6 & 7.7 \\
Finland & 80.4 & 8.0 & 5.5 & 4.5 & 1.5 \\
France & 53.0 & 5.5 & 9.0 & 13.7 & 18.8 \\
Germany & 35.5 & 12.6 & 12.3 & 11.2 & 28.2 \\
Greece & 75.9 & 13.8 & 4.6 & 4.0 & 1.7 \\
Netherlands & 32.4 & 7.0 & 7.0 & 14.8 & 38.9 \\
Portugal & 70.7 & 25.7 & 2.0 & 2.0 & 1.5 \\
Spain & 67.4 & 19.0 & 3.8 & 7.6 & 2.3 \\
Sweden & 38.7 & 14.5 & 9.0 & 11.1 & 26.6 \\
UK & 43.2 & 10.2 & 8.0 & 13.6 & 25.0 \\
\hline
\end{tabular}



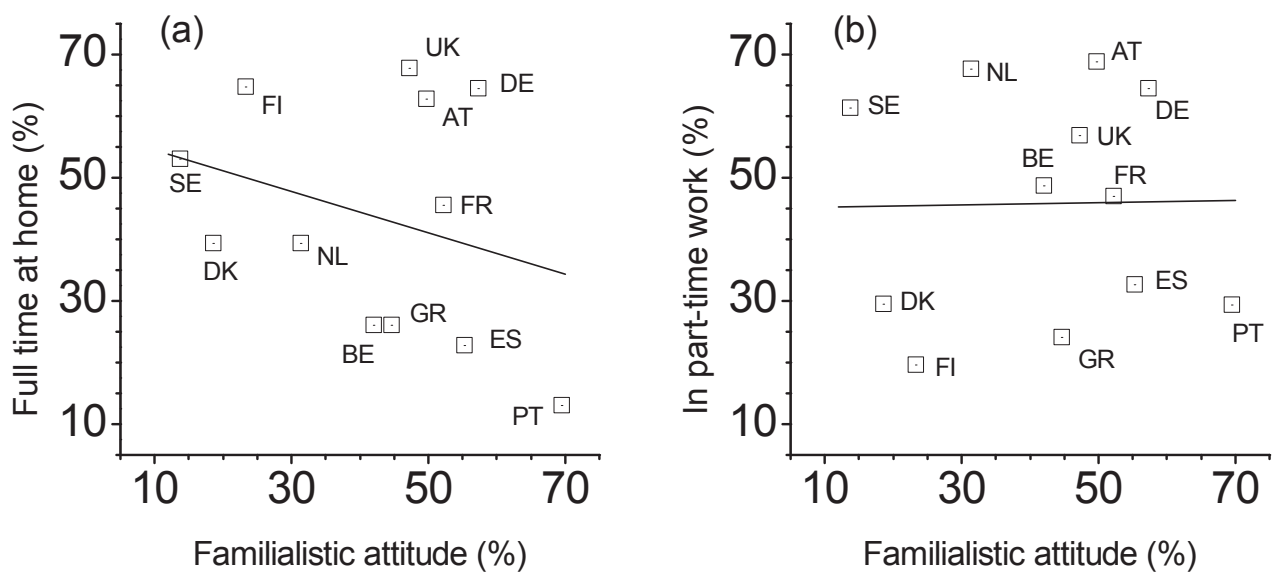

Figure 2Aa. More than two years full-time at home (\%) versus familialistic attitude $(\%)$ in the twelve countries (see Fig. 1 for the countries). The solid line shows a least squares fit to the values ( $p$-value is 0,342 ).

Figure 2Ab. Part-time work participation (\%) versus familialistic attitude (\%) in the twelve countries (see Fig. 1 for the countries). The solid line shows a least squares fit to the values ( $p$-value is 0,961 ). 
